\title{
Obstacles to the Russian Modernization Agenda Through a Two-Level Analysis Approach
}

\author{
Marielle DeVos ${ }^{1}$ and Jill Berge ${ }^{1 \#}$ \\ ${ }^{1}$ Lake Washington High School, Kirkland, WA, USA \\ \#Advisor
}

\section{$\underline{\text { ABSTRACT }}$}

Economic modernization in Russia is heavily reliant on increased market competition and diversity within the Russian economy. However, modernization has been largely unsuccessful due to a misalignment between the goals of the Russian modernization agenda, including those in the PCA and P4M, and the state's behavior both domestically and internationally. This study finds that domestic institutions within Russia continue to execute on a legislative agenda contradictory to their modernization agenda due to both state security priorities and the power imbalances within the government.

\section{Introduction}

Since the end of the Cold War period, the European Union (EU) and Russia have developed economically and politically separate of each other. While the EU is the world's largest single market area and most outward oriented economy, the Russian economy remains in need of modernization. According to a study (2015) by Dr. Richard Connolly, director of the Centre for Russian, European, and Eurasian Studies at the University of Birmingham, the Russian economy is overly dependent on natural resources and struggles with comparatively low rates of productivity growth compared to its European counterparts (Connolly, 2015). Starting in 1994 with the signing of the Agreement on Partnership and Cooperation between Russia and the EU, Russia has tried to modernize and strengthen its economy and partnership with the European Union. Thus, this paper aims to examine the goals and obstacles faced by Russia in its effort to modernize its economy in partnership with the EU using Putnam's two-level game theory.

\section{Review of the Literature}

In 1988, Professor Robert Putnam developed his two-level game theory for international negotiations. Two-level game theory describes international negotiations as a two-table game. At the domestic board, negotiators must contend with policymakers, interest groups, businesses, and citizens. At the international board, negotiators face pressure from their foreign counterparts, multinational businesses, and other diplomats. A move that is rational or strategic at the external board may be impolitic at the domestic board or vice versa (Putnam, 1988).

For an agreement or initiative to be successful, there are two levels that the agreement must pass through before it can be ratified. A level I agreement is the initial bargaining between negotiators that leads to a tentative agreement. At level II, agreements are brought to each negotiator's domestic constituents and the decision to ratify the agreement is made (Putnam, 1988). For the level II constituency, there is a win-set of all possible level I agreements that could gain majority support among constituents. The larger the win-set, the more likely a level I agreement is to be reached, as long as outside conditions remain the same; any successful agreement will have to fall into the win-set of both parties. Conversely, the smaller the win-set for either party, the more likely negotiations are to break down 
(Putnam, 1988). Two-level game theory is used to analyze international agreements and negotiations, both past and present; however, this study will focus primarily on the ratification of agreements and goals at Level II.

When applied to economic modernization, two-level games must account for the need to maintain the legitimacy of the political regime. According to a peer-reviewed paper by Professor Richard Bellamy and Professor Albert Weale (2015), normative legitimacy encompasses the set of standards by which an institution or regime is judged (Bellamy and Weale, 2015). Normative legitimacy is the credibility of a regime, and the state can lose its credibility among domestic stakeholders if its international actions contradict its constituents' best interests. When a condition of normative legitimacy is violated, level II agreements become more difficult because the institution must maintain its legitimacy with its stakeholders. In this case, the Russian modernization agenda must consider the government's legitimacy. If the agenda, agreed on by both Russia and the EU, contradicts the interests of the state, key actors at level II will have to choose between their self-interest or supporting the agenda. This is made more difficult by Russia's political landscape, which is controlled unilaterally by Vladimir Putin.

A case study in the convergence of normative logic and two-level games can be found in the EU's efforts at partnership with Russia for the sake of economic modernization.

According to an article on the relationship between Russia and the EU by Maxine David and Tatiana Romanova (2015), published in the peer-reviewed journal European Politics and Society, since the end of the Cold-War, Russia and the EU have economically developed separate of each other. Despite agreements such as the Agreement on Partnership and Cooperation (PCA) and its four common spaces (encompassing economy; freedom, security and justice; external security; research and education), as well as the Partnership for Modernization (P4M), relations between the EU and Russia have been deteriorating (David and Romanova, 2015).

In a peer-reviewed paper analyzing the contradictions of the Russian modernization agenda (2015), Professor Paul Flenley from the University of Portsmouth explains that the Partnership for Modernization (P4M) outlines the future relationship between the EU and Russia and is meant to replace the PCA. Past agreements such as the PCA failed primarily because of an asymmetry of interests between the two. The EU's main interest was, and still is to some extent, in promoting democracy and open markets, while Russia's main interest is regaining its status as a great power, the key to this being restoring the power of the Russian economy (Flenley, 2015). The P4M differs from the PCA in the sense that it aims to promote alignment of technical regulations and standards, ensure proper functioning of the judiciary in the fight against corruption, and foster economic participation of individuals and businesses (Flenley, 2015). The motivation for the EU remains that democratic norms can be transferred indirectly and effectively through economic and politically neutral relationships, as more direct attempts, such as the PCA, were unsuccessful.

For Russia, the P4M is a chance to strengthen the economy by building relationships with the EU and its members, as well as restructuring its economy similar to the EU. According to Playing the Market: A Political Strategy for Uniting Europe, 1985-2005 (2006), a volume in the series Cornell Studies in Political Economy, the EU has used the competitive market as the norm for economic organization (Jabko, 2006). The market and "market rationality" have been used to justify policy and trade agreements. More importantly, the market is used to drive development and diversity within the economy (Jabko, 2006). For Russia to modernize, it needs to do just that: diversify its economy away from raw materials and increase economic development and innovation, thus making a competitive market crucial to its modernization.

According to a peer-reviewed paper by Richard Connolly (2015) from the Centre for Russian, European, and Eurasian Studies at the University of Birmingham, while Russia's accession to the World Trade Organization in 2012, which included extended negotiations with the EU, did benefit Russia's economy, it is still largely dependent on the extraction of natural resources, which is not sustainable long-term (Connolly, 2015). This was seen during the 2008 global financial economic crisis, when Russia fared especially poorly compared to its European neighbors due to its lack of economic support. Connolly's analysis demonstrated the impact that integration can have on economic modernization, but also that conditions domestically must change in order for success to be achieved.

While current research has studied the conditions of particular agreements and the historical context of the economic relationship between Russia and the EU, little has been done to study the modernization goals of this 
relationship in the context of international and domestic politics through a theoretical approach. In the case of this paper, Putnam's two-level game theory can be used for a theoretical analysis of international agreements, state policies, and the domestic conditions that impact them. Thus, similar to other analyses of international agreements, this study uses a levels of analysis approach; however, the levels have been based on two-level game theory.

\section{Methods}

The first step to examining the obstacles facing Russia's modernization agenda and its partnership with the EU was to analyze Russia's goals and its relationship with the EU using Putnam's two-level game theory to form two levels of analysis. While theoretical analysis is not the most common approach to studying EU-Russia economic relations, this methodology allowed for a more thorough analysis of the influencing factors around international politics. Similar to Professor Romanova's three-level analysis of the P4M, this study also used levels of analysis to analyze international agreements; however, it went beyond just the P4M and used two-level game theory as the foundation to analyze the obstacles faced by the Russian government and their impact on negotiations (Romanova, 2015).

The first distinction that was made was between international and domestic policy. International policy was defined as any agreement or partnership between two or more nations or international organizations. Domestic policy was defined as any strategy, agenda, legislation, report, or order passed by either party domestically (or in the case of the EU, internally). Table 1 summarizes the different categories and their respective constituencies. The first level of analysis, level I, analyzed past international agreements from the international perspective based on what each party would gain and concede, impacts on the security of each party, impact on other relationships, and the policy conditions that would have to be met. Domestic policy was analyzed on this level with a similar set of measures: the effects on outside parties, the conditions that would have to be met, impact on national security, and impact on external relationships. The second level, level II, analyzed international agreements from the domestic perspective, based on the impact the agreement would have on each sector of the economy, the impact on politics and law, and the impact on education and poverty. Domestic policy was analyzed at level II based on the same conditions as international agreements. The two levels of analysis were derived from Professor Putnam's two-level game theory for international negotiations, and the conditions at each level were created based on an analysis of the P4M done by Professor Flenley, Professor Connolly's analysis of the conditions of Russia's accession to the WTO, and the European Parliament's Seven Economic Challenges for Russia report (2018). The socio-economic and political conditions aligned with those analyzed in the EU's report, and the economic and security conditions came primarily from Professor Flenley and Connolly.

Table 1. International agreements and domestic policies and their relative constituents

\begin{tabular}{|l|l|l|}
\hline Type & Classifications & Constituents \\
\hline International & $\begin{array}{l}\text { Roadmaps, partnerships, agreements (trade or } \\
\text { otherwise), mechanisms, progress reports }\end{array}$ & $\begin{array}{l}\text { Multinational businesses and indus- } \\
\text { tries, international markets, domestic } \\
\text { policymakers, international institu- } \\
\text { tions }\end{array}$ \\
\hline Domestic & $\begin{array}{l}\text { Legislation, strategy, agendas, regulations, } \\
\text { goals, budgets, addresses, orders, reports }\end{array}$ & $\begin{array}{l}\text { Interest groups, economic industry } \\
\text { leaders, other policymakers, citizens }\end{array}$ \\
\hline
\end{tabular}

The international agreements and domestic policies that were analyzed were selected based on when they were passed/negotiated (time) and their scope and impact. All policy and agreements analyzed were negotiated and signed in 1994 or later. This cutoff was chosen because the PCA, the precursor to the P4M, was signed in 1994 and has laid the groundwork for all economic policies since then. For scope, all documents analyzed had to relate directly to the economic common space and/or the Russian modernization agenda. For the economic impact, all policy and 
agreements analyzed were focused specifically on modernization of the Russian economy and/ or economic relations between Russia and the EU. This approach of theoretical multi-level analysis was laid out by Professor Romanova in 2015. The combination of her multi-level theoretical analysis method and Putnam's two-level game theory laid the groundwork for this study.

Following these criteria, the documents selected were the Roadmap for the Common Economic Space, the Progress report Agreed by the Coordinators of the EU-Russia Partnership for Modernization for Information to the EU-Russia Summit of 21 December 2012, the Roadmap for EU-Russia Energy Cooperation until 2050, and the Commission Staff Working Document on significant distortions in the economy of the Russian Federation for the purposes of trade defense investigations. While optimally the P4M would have been analyzed as part of this study, the P4M mechanism was not accessible to the public. The domestic documents selected were the Presidential Address to the Federal Assembly (March1, 2018) and Executive Order 204 (May 7, 2018). The domestic documents chosen were documents that were part of the paper "Strategic Planning - the Way Toward Sustainable Development of the Russian Economy" (2018) written by Elena Len'chuck, director at the RAS Institute of Economics, and Vladimir I. Filatov, head of the Center for Innovation Economy and Industrial Policy at the RAS Institute of Economics. Len'Chuck and Filatov analyzed the strategic planning of Russia for sustainable economic development, and, similar to this paper, focused on obstacles Russia faced to achieving its goals and implementing policy (Len'Chuck and Filatov, 2018). Table 2 summarizes the applicable criteria used to analyze each document, as not every document impacted each stakeholder at each level. While the conditions to be met (for domestic documents) and the gains and concessions (for international documents) were analyzed as part of the study's method, the data gained from them was used to inform the discussion of the study's results, rather than contribute to the results themselves.

Table 2. Criteria applicable to each document ${ }^{1}$

\begin{tabular}{|l|l|l|}
\hline Document & Level I & Level II \\
\hline $\begin{array}{l}\text { Document 1. Presidential Address to the Fed- } \\
\text { eral Assembly }\end{array}$ & $\begin{array}{l}\text { Effect on outside parties, impact on } \\
\text { national security, conditions, impact } \\
\text { on other relationships }\end{array}$ & $\begin{array}{l}\text { Impact of economic sectors, Politics } \\
\text { and law, education, poverty }\end{array}$ \\
\hline $\begin{array}{l}\text { Document 2. Executive Order } 204 \\
\text { Effect on outside parties, conditions }\end{array}$ & $\begin{array}{l}\text { Impact of economic sectors, Politics } \\
\text { and law, education, poverty }\end{array}$ \\
\hline $\begin{array}{l}\text { Document 3. Roadmap for the Common Eco- } \\
\text { nomic Space }\end{array}$ & $\begin{array}{l}\text { Gains and concessions made, impact } \\
\text { on national security, impact on other } \\
\text { relationships }\end{array}$ & $\begin{array}{l}\text { Impact of economic sectors, Politics } \\
\text { and law, education }\end{array}$ \\
\hline $\begin{array}{l}\text { Document 4. Commission Staff Working Docu- } \\
\text { ment (Secondary Source) }\end{array}$ & $\begin{array}{l}\text { Effect on outside parties, impact on } \\
\text { national security }\end{array}$ & $\begin{array}{l}\text { Impact of economic sectors, Politics } \\
\text { and law, education, poverty }\end{array}$ \\
\hline $\begin{array}{l}\text { Document 5. Progress report Agreed by the Co- } \\
\text { ordinators of the EU-Russia Partnership for } \\
\text { Modernization }\end{array}$ & $\begin{array}{l}\text { Gains and concessions made } \\
\text { Impact of economic sectors, Politics } \\
\text { and law }\end{array}$ \\
\hline $\begin{array}{l}\text { Document 6. Roadmap for EU-Russia Energy } \\
\text { Cooperation until 2050 }\end{array}$ & $\begin{array}{l}\text { Gains and concessions made, impact } \\
\text { on national security, impact on other } \\
\text { relationships }\end{array}$ & $\begin{array}{l}\text { Impact of economic sectors, Politics } \\
\text { and law, education, poverty }\end{array}$ \\
\hline
\end{tabular}

Once the documents were analyzed on both levels I and II and the data had been collected and analyzed, the goals laid out in these documents were compared to the policy decisions and legislation that was passed. Following two-level game theory as laid out by Professor Putnam, the win-set for Russia, being all possible agreements and policies that would pass at both Level I and Level II, was used in the analysis to explain differences between goals

\footnotetext{
${ }^{1}$ Listed in Appendix A
} 
and actual policy decisions. There are three win-set determinants, but only two were applicable to the study: level II preferences and coalitions and level II institutions. The determinants and their respective explanations are displayed in Table 3. While the third determinant, negotiation strategy, was not crucial to this study, preferences and coalitions as well as institutions were critical to analyzing the results.

Table 3. Win-set determinants as defined by two-level game theory and Professor Putnam

\begin{tabular}{|l|l|}
\hline Level II Preferences and Coalitions & $\begin{array}{l}\text { The lower the cost of no-agreement to constituents, the smaller the win- } \\
\text { set. Ratification pits the proposed agreement against no-agreement. }\end{array}$ \\
\begin{tabular}{|l} 
Level II institutions \\
Ratification Procedures affect the size of the win-set. If a $2 / 3$ majority is \\
required for ratification then the win set will be smaller than if only a \\
simple majority were required. \\
The greater the autonomy of central decision-makers from their Level II \\
constituents, the larger their win-set, and thus the greater the likelihood \\
of achieving international agreement.
\end{tabular} \\
\hline $\begin{array}{l}\text { Negotiation Strategy } \\
\text { other side's win-set, but with respect to his own win-set. }\end{array}$
\end{tabular}

After the documents were analyzed following the specific criteria laid out for each level and each type of document, the results were compiled to display Russian modernization goals and obstacles faced at each level so as to explain the difference between goals and state policies.

\section{Results}

As stated in the methodology section, the first step taken was to analyze various documents (listed in Section III). The documents were analyzed differently depending on whether they were an international agreement or domestic policy. The differences between the two types of documents are displayed in Table 1. Depending on their classification they were analyzed on different criteria, displayed in Table 2 . The results of the document analysis are categorized by the three main themes that each document focused on: security and defense, economic sector goals and impacts, and public policy and state participation in the economy; however, as stated in the methods section, all documents and themes were in relation to economic modernization goals. The level II criteria focusing on education and poverty falls within the theme of public policy and state participation in the economy. The three themes cover both level I, international, and level II, domestic.

\section{Impact on Economic Sectors and Sector Specific Goals}

The largest portion of Russia's modernization agenda revolves around various economic sectors and sector specific goals. The primary goals, as laid out in Documents 1, 2, 3, and 6, are to create an attractive investment climate and increase the role of investment in the Russian economy, to modernize technology and infrastructure, and to spur overall economic development. Table 4 displays Russia's sector specific goals, and Table $\mathbf{5}$ displays sector specific goals for Russia's partnership with the EU. 
Table 4. Sector specific goals in the Russian economy

\begin{tabular}{|c|c|}
\hline Sector & Goals \\
\hline Social Services & $\begin{array}{l}\text { Healthcare: spend } 4 \% \text { of GDP on healthcare system from 2019- } \\
2024 \text { and aim to increase spending to } 5 \% \text { (Document } 1 \text { ) } \\
\text { Housing: Increase the volume of housing built annually from } 80 \\
\text { million to } 120 \text { million square meters (Document } 1 \text { ) }\end{array}$ \\
\hline Transportation and Infrastructure & $\begin{array}{l}\text { Roads: In } 6 \text { years, double spending on road construction and repairs, } \\
\text { allocating at least } 11 \text { trillion roubles (Document } 1 \text { ) } \\
\text { Railways: Capability of Baikal-Amur Mainline and Trans-Siberian } \\
\text { railway will grow } 1.5 \mathrm{x} \text {, up to } 180 \text { million tonnes, in } 6 \text { years (Docu- } \\
\text { ments } 1 \text { and } 2 \text { ) } \\
\text { Increase capacity of railway links in the Azov and Black Sea basin } \\
\text { 1.5-fold to } 131 \text { million tonnes (Documents } 1 \text { and } 2 \text { ) }\end{array}$ \\
\hline Technology and Telecommunications & $\begin{array}{l}\text { Technology: Build digital platforms compatible with the global in- } \\
\text { formation space } \\
\text { Technology Enterprises: Become a global center for storage, pro- } \\
\text { cessing, transfer, and reliable protection of information and data } \\
\text { Internet and Telecommunication: By } 2024 \text {, high-speed internet will } \\
\text { be available throughout Russia (Document } 1 \text { ) }\end{array}$ \\
\hline Energy, Gas, and Power & $\begin{array}{l}\text { Power: By } 2024 \text {, attract } 1.5 \text { trillion rubles in private investment for } \\
\text { modernizing the power generation sector. } \\
\text { Modernize thermal power plants, boiler houses, and utility services } \\
\text { (Document } 1 \text { ) } \\
\text { Energy: Double amount of non-resource/energy exports to reach } \\
\$ 250 \text { billion } \\
\text { Gradual and progressive reform of the Russian gas sector to align } \\
\text { with the Energy strategy of the Russian Federation until } 2020 \text { (Doc- } \\
\text { ument } 3 \text { ) }\end{array}$ \\
\hline Investment, Finance, and Business & $\begin{array}{l}\text { Investment: Investment should be the second largest source of eco- } \\
\text { nomic growth, with it making up } 25 \% \text { of GDP with final goal being } \\
27 \% \text { (Document } 1 \text { ) }\end{array}$ \\
\hline Trade and Economics & $\begin{array}{l}\text { Partnership with the Eurasian Economic Union seeks to create a } \\
\text { globally competitive integration group } \\
\text { EAEU's agenda includes a common electricity, oil, petroleum, and } \\
\text { the harmonization of financial markets (Document } 4 \text { ) }\end{array}$ \\
\hline Labor & $\begin{array}{l}\text { labor productivity in medium-sized and large enterprises, such as } \\
\text { manufacturing, construction, transport, agriculture, and trade grows } \\
\text { at least } 5 \% \text { each year (Document } 1 \text { ) }\end{array}$ \\
\hline
\end{tabular}


Table 5. Sector-specific goals for the Russia-EU Partnership

\section{Transportation and Infrastructure}

Technology and Telecommunications

Energy, Gas, Natural Resources, and Power

Investment, Finance, and Business

Trade, Economics, and Customs
Transportation: promote the complementarity of Russian and EU transport sectors (Document 3)

Infrastructure: implement infrastructure projects and priority transport corridors of mutual interest (Document 3)

Telecommunication: Cooperate on joint projects in space applications on broadcasting, telecommunication, and broadband media systems (Document 3)

Energy: By 2050, Russia and the EU will be part of a sub-continentwide common energy market (Document 6)

Promote and protect investments in the energy sector (Document 3 ) Investment: Create favorable conditions for investment by implementing international standards (Document 3)

Accounting: Adopt the highest international standards for accounting and financial reporting in both the EU and Russia (Document 3)

Business: Promote small and medium-sized enterprises (SMEs) (Document 5)

Provide financial support to the Russian SME Agency to further development of the Enterprise Europe Network in Russia (Document 5)

Trade: Facilitate, standardize and automate procedures connected with external trade (Document 3)

Exchange information prior to development and implementation of measures impacting trade or facilitation of trade (Document 3)

Simplify trade-related legislation (Document 3)

However, in many sectors, state ownership and control has increased rather than decreased. This directly contradicts the goals set forth in documents 3, 5, and 6. Tables 6 and 7 display state ownership in various forms, including state-owned enterprises (SOEs) and joint-stock companies.

Table 6. State share of the economy in specific sectors

\begin{tabular}{|l|l|}
\hline Enterprise & Government Participation \\
\hline Gas (via gas monopolist Gazprom) & $\begin{array}{l}\text { Russian state ownership increased from 38\% to 50\% af- } \\
\text { ter } 2005\end{array}$ \\
\hline Energy & $\begin{array}{l}\text { Rosatam (Nuclear) and RusHydro (Hydro Electric): } \\
\text { state holds majority shares }\end{array}$ \\
\hline Transport & $\begin{array}{l}100 \% \text { state ownership of Russian railways, Shere- } \\
\text { metyevo International Airport, United Shipbuilding } \\
\text { Corporation }\end{array}$ \\
\hline Banking & $\begin{array}{l}\text { State ownership of banking assets estimated to be as } \\
\text { high as 70\% in 2017 }\end{array}$ \\
\hline
\end{tabular}


Table 7. Ownership of major Russian corporations (Russel, 2018)

\begin{tabular}{|l|l|}
\hline Corporation & Ownership \\
\hline Gazprom (gas)* & state-owned \\
\hline Surgutneftegaz (oil/gas)* & private \\
\hline Rosneft (oil)* & state-owned \\
\hline Lukoil (oil)* & private \\
\hline Rosatom (Energy) & state-owned \\
\hline RusHydro (Energy) & state-owned \\
\hline Russian Railways* (transport) & state-owned \\
\hline Sberbank (finance)* & state-owned \\
\hline VTB Bank (finance)* & state-owned \\
\hline Rostech (investment)* & private \\
\hline Magnit (retail)* & private \\
\hline X5 Retail Group (retail)* & private \\
\hline
\end{tabular}

*top-ten company

\section{Defense and National Security vis a vis Economic Goals}

The main goals in Russia's modernization strategy relating to security and defense were described in Document 1. Putin states that "technological lag and dependence translate into reduced security and economic opportunities of the country and, ultimately, the loss of its sovereignty" (Document 1). Russia's defense and security goals in relation to its economic modernization are to increase productivity and increase economic growth in areas of strategic importance for national defense. However, both domestic and external policy have impeded this goal.

Domestically, Russian state participation and regulation of the economy limits access by foreign investors and favors state ownership, thus limiting competition and overall growth. Article 6 of the Strategic Investments Law lists all 42 activities and business enterprises of strategic importance to national defense and state security; however, these industries and activities are not solely used for national defense. Thus, the restrictions placed on them by the Strategic Investments Law and the Foreign Investments Law have limited the investment climate as a whole, which hampers economic growth in these areas, as many of them fall in the industrial and technological sectors of the economy. This makes it difficult for these "strategic sectors" to grow and outcompete those in economies more favorable to investment. Table 8 displays the specific restrictions to foreign investment placed on each economic sector by the Strategic Investments Law.

Table 8. Restrictions on foreign investment in sectors of strategic importance (Document 4)

\begin{tabular}{l|l}
\hline Sector/ Activity & Restriction \\
\hline $\begin{array}{l}\text { Extraction of raw materials/mining: fed- } \\
\text { eral subsoil plots }\end{array}$ & $\begin{array}{l}\text { (Article } 6 \text { of the Strategic Investments Law) Foreign investors must gain consent of the Com- } \\
\text { mission on Monitoring Foreign Investment if they seek }\end{array}$ \\
& $\begin{array}{ll}\text { i. } \quad \text { Ownership of } 25 \% \text { or more voting shares } \\
\text { ii. } \quad \text { Right to appoint individual executive body or } 25 \% \text { or more of the members of } \\
\text { the management body }\end{array}$ \\
& iii. $\quad$ Any other ability to control the decisions of the strategic company
\end{tabular}




\begin{tabular}{|c|c|}
\hline $\begin{array}{l}\text { Extraction of raw materials/mining: } \\
\text { non-federal subsoil }\end{array}$ & $\begin{array}{l}\text { (Article } 6 \text { of the Strategic Investments Law) Preliminary consent of government required if } \\
\text { foreign investors acquire } \\
\begin{array}{cl}\text { i. } & \text { more than } 50 \% \text { of votes at shareholder level } \\
\text { ii. } & \text { right to appoint chief executive officer and/or more than } 50 \% \text { of executive body } \\
\text { iii. } & \text { ability to elect more than } 50 \% \text { of members of the board of directors or other } \\
& \text { governing body }\end{array}\end{array}$ \\
\hline
\end{tabular}

If investors are controlled by foreign governments or are in certain jurisdictions, prior approval is required for all transactions that would allow the acquisition of more than $25 \%$ of voting shares or other rights

Telecommunication and data

(Article 3 (2) of Strategic Investments Law)

i. Prior approval is necessary for any transaction in which a foreign investor acquires control over any business in the telecommunications sector

ii. Licenses are required for such activities as the provision of communication or broadcasting services

iii. Russian data localization law requires companies operating in Russia to store Russian users/client's data on servers physically located in Russia

Metallurgical production

Electricity, gas, steam
(Article 4 of Strategic Investments Law) Transactions establishing control by a foreign investor over a business entity must receive the consent of the FAS

Metallurgical companies that produce metals or alloys that are used in military equipment are subject to these regulations

i. The share of foreign investors cannot exceed $20 \%$ of the total ordinary shares

ii. The total sum of shares of owners of the Unified Gas Supply System cannot exceed $50 \%$, and other $50 \%$ of shares must belong to the government

The restrictions placed on foreign investments and foreign participation in the Russian economy in areas of strategic importance limit the access to the market for investors and hinder growth in those sectors, especially because major corporations in those sectors are partially or fully owned by the government (state owned enterprises or SOEs). The 42 industries considered under these laws are those where increased investment would be most beneficial for the economy overall.

Internationally, Russia has faced sanctions from both the United States and the EU for its activities in Ukraine and its weapons development programs. In the defense sphere, Russia is threatened by the United States' withdrawal from the Anti-Ballistic Missile Treaty and disregard for the New START Treaty (Document 1). The New START Treaty was signed between Russia and the United States in 2010 to further reduce and limit the development and expansion of strategic offensive arms; however, U.S. plans to build a global antiballistic missile system have devalued the treaty. The eastward expansion of NATO and the close relationship between the U.S. and EU further the perceived threat to Russia and thus increase its need to develop weapons, which incurs further sanctions.

\section{Public Policy and State Participation in the Economy}

Domestic policy in Russia includes overarching goals in different policy areas. Table 9 displays domestic policy goals in Russia in the social, fiscal, and legal spheres. 
Table 9. Domestic policy goals of Russia

\begin{tabular}{|c|c|c|}
\hline Policy & Goal & \\
\hline Social & $\begin{array}{l}\text { i. } \\
\text { ii. } \\
\text { iii. }\end{array}$ & $\begin{array}{l}\text { Cut poverty in half (Document 2) } \\
\text { Improve housing for at least } 5 \text { million households annually (Document } 2 \text { ) } \\
\text { Build an open and modern school management system and modernize the vocational } \\
\text { education system (Document } 1 \text { ) }\end{array}$ \\
\hline Fiscal & $\begin{array}{l}\text { i. } \\
\text { ii. } \\
\text { iii. } \\
\text { iv. } \\
\text { v. } \\
\text { vi. }\end{array}$ & $\begin{array}{l}\text { Keep inflation below } 4 \% \text { (Document } 2 \text { ) } \\
\text { Guarantee sustained long-term income growth (Document } 1 \text { ) } \\
\text { Investment should be second largest source of growth (Document 1) } \\
\text { Increase per capita GDP by } 50 \% \text { (Document 1) } \\
\text { Economic growth rates should exceed global rates (Document 1) } \\
\text { State must reduce its share in the economy (Document 2) }\end{array}$ \\
\hline Legal & $\begin{array}{l}\text { ii. } \\
\text { iii. }\end{array}$ & $\begin{array}{l}\text { Establish new taxation rules that will be stable and fixed for the first few years and } \\
\text { revise the property tax (Document } 1 \text { ) } \\
\text { Strengthen the rule of law and legal environment (Document } 5 \text { ) } \\
\text { Set up an appeal system for civil and criminal court cases (Document 5) }\end{array}$ \\
\hline
\end{tabular}

One of the central goals of Russia's modernization strategy and the P4M is to reduce the state's share in the economy and increase investment and business in order to strengthen the economy and boost economic growth. In order to achieve the goals in Table 9, Russia must do this. Instead, state participation in the economy has increased rather than decreased as shown in Tables 6 and 7. Because of the disconnect between domestic action and domestic goals, policy in Russia becomes self-defeating because it interferes with its sector specific and security goals. While the goals all align, the policy actions do not. For example, fiscal goal vi aligns with goals laid out in the P4M, as well as Document 3. However, domestic policy has increased the state's share in the economy as previously mentioned, thus hampering the goals of Russia's partnership with the EU as well as its external security goals.

\section{Discussion and Analysis}

Russia's modernization goals, especially in partnership with the EU, do not align with the legislation and policy that gets passed. Many of the goals are reliant on Russia's ability to cooperate with and harmonize legislation and market regulations with outside groups and countries. However, Russian renationalization of the economy starting in 2015 (Document 4) has increased the state's participation in the economy, rather than decreasing it as was one of the goals of the P4M and is central to successfully modernizing the economy.

In the report commissioned by the European Parliament, entitled Seven Economic Challenges for Russia, the feasibility of Vladimir Putin's economic goals was brought into question. Much like the report, this study found a large difference between goals stated by Vladimir Putin and the Russian government and the policy actions that were actually taken. As shown in Tables 6 and 7, major Russian corporations and industries are still a majority owned or partially owned by the state. Of the top-ten major corporations, $50 \%$ are state controlled, and out of all twelve corporations listed, 58.3\% are state-controlled. This is in direct conflict with fiscal goal v, listed in Table 9.

Russia's focus on strategic weapons development has led to international sanctions as well as domestic policy that hampers its economic development goals. Because of Russian actions in Ukraine and the ongoing development of ballistic weapons systems, Russia has been sanctioned by both the EU and the United States. The Russian Economy in 2018 Trends and Outlooks report released by the Gaidar Institute estimates the impact of these sanctions on Russia's economic growth and success. These sanctions are a significant obstacle to Russian economic growth, as sanctions “destabilize socio-economic processes and hamper quick adaption to potential challenges” (Alexander et al., 2018). 
This leads to fluctuations in the financial market and instability in the value of the ruble. It also hampers Russia's investment goals as sanctions make foreign investors unwilling or unable to partner with Russian companies. The results of this study, specifically those displayed in Table 8, in combination with those of the Gaidar Institute's report, display two strong obstacles to Russian economic modernization.

This is an example of where normative legitimacy, as explained in Section II, comes into play with Russia's modernization agenda. The state's legitimacy rests on the "necessity" of protecting Russian interests above all else. Because of sanctions by both the EU and USA, the state interest turns to denying the legitimacy of the sanctions and reaffirming the legitimacy of state policies and actions. Thus, while it would be in the best economic interest of Russia to decrease limits on foreign investment in "strategic sectors", denationalize the economy, and allow for greater foreign participation in the economy, doing so would require policy concessions that would legitimize the sanctions and delegitimize the actions that led to the sanctions, so the state instead chooses to strengthen its role in the economy and limit cooperation with foreign partners.

However, it must be noted that one limitation of using normative legitimacy is that it assumes the regime in power is a democratic one. However, the Russian government under Vladimir Putin is an authoritarian regime, where governing power is concentrated almost solely with Putin. While normative legitimacy can still be used to explain the Russian government's behavior, maintaining "legitimacy" is less important under an authoritarian regime than a democratic one. According to a paper by Alex Levitov, a postdoctoral fellow at the Center for Ethics in Society at Stanford University, in a democratic system, normative legitimacy is absolutely necessary for the governing group to maintain its "mandate" because its legitimacy comes directly from those who elect it. In other words, the state's legitimacy arises from the social contract between the governed and the government (Levitov, 2016). In an authoritarian regime such as Russia, normative legitimacy is still valid, but the risk of violating the social contract is much smaller because the regime's authority over the public supersedes its legitimacy in the eyes of the public. Instead, the legitimacy that must be maintained is with the State Duma, not the general public. So, while this theory is more often applied to democratic regimes, it can still be used with an authoritarian one, so long as it focuses on the alternative group where legitimacy must be maintained.

Including its partnership with the EU, Russian economic modernization goals with outside partners traverse multiple economic sectors. However, Russian policy is in direct contradiction to these goals, which can be seen both in its partnership with the EU, as well as with the Eurasian Economic Union (EAEU). Within the EAEU, key decisions are still made by the governments of member states, operating as an intergovernmental organization rather than as a supranational one (Document 4). While Russian goals within the EAEU include a common market for goods, oil, gas, and energy as well as the harmonization of financial markets (Table 4), state control over the economy presents a barrier to these goals. Legislation, tax codes, and regulations are still made independently by the Russian government, meaning that any market integration is limited due to misalignment between Russia and other EAEU members. It is estimated that the goods market is integrated at only $40 \%$ potential, services at $20 \%$, labor at $60 \%$, and capital at $10 \%$ (Document 4). With the EU, most goals laid out in Document 3 rely on Russian adoption of international standards or increased competition in the Russian market, as displayed in Table 5. However, due to Level II preferences and coalitions and Level II institutions (as explained in Table 3), despite ratification of these agreements few of the policy goals have actually been implemented. This is due to the institutions and coalitions within Russia. Because the agreements don't enforce the adoption of policies, the coalitions, mainly Putin's, in power and the institutions within Russia have no incentive to adopt new policies that could subtract some of their power. If the agreements had enforced the adoption of specific policy, they most likely would not have been ratified in the first place. This is the same reason that Russia has had little success in accomplishing legal goals ii and iii. There is no real penalty for not accomplishing these goals, and thus domestic institutions, which are controlled by Vladimir Putin, are unlikely to do so because it would not benefit them. If there had been a penalty for not accomplishing them, the agreement that led to their origin would not have been ratified at level II to begin with. The preferences at level II are also an obstacle both to integration within the EAEU and accomplishing legal goals ii and iii. There is little to no "cost" for the institutions in power to 
not integrate or accomplish the goals because if there had been a "cost" to not integrating or not accomplishing the goals, the agreement would not have been ratified.

Domestic policy goals in Russia, displayed in Table 9, focus on strengthening the Russian economy and increasing economic growth. However, these goals are still hampered by both domestic and international actions. Specifically, fiscal goals ii, iii, v, and vi are disrupted by both Russia's foreign investment laws, sanctions placed on Russia, and renationalization of the Russian economy. Russia's foreign investment laws (Table 8) and state control of the economy limit the amount of growth that can come from investment. This obstructs fiscal goal iii, that investment should be the second largest source of economic growth, and actively goes against fiscal goal vi, that the state should reduce its share in the economy. Because of the obstacles to success surrounding fiscal goals iii and vi, accomplishing fiscal goals $i$ and $v$ becomes more difficult. Fiscal goal ii, sustained economic growth, relies on fiscal goal iii. Without the economic gains provided by increased investment, sustained economic growth is limited, and without the state reducing its share in the economy (fiscal goal vi), it will be difficult to have sustained economic growth, let alone growth rates that outpace global growth (fiscal goal $v$ ).

This makes social goals $i$-iii, as well as the social services goals in Table 4, more difficult. Increasing spending on the healthcare system, housing, and education requires increased government revenue and economic growth. Without that growth and revenue, increasing spending on social services becomes more difficult. This in turn makes it more difficult to lower the poverty rate (social goal $i$ ), because there is not as much funding for social services.

Based on the results of the two-level analysis, Russian modernization goals are obstructed by the interests of domestic institutions. Even when goals are made by the institutions themselves, such as in Document 1, the institutions and coalitions in power are unwilling to take the steps required to reach those goals. For example, the goal of increasing investment in Table 9 is made by the coalitions/institutions in power; however, the steps necessary to achieve this goal, such as decreasing state shares in the economy and relaxing foreign investment laws, go against the interests of the groups in power.

\section{Conclusion}

The level-of-analysis approach used in this study allows researchers to analyze policies and agreements from both the domestic and international perspectives. Along with two-level game theory, the ideas of normative legitimacy and political constitutionalism, which was not discussed in this study, could be used to further understand the political motivations of both domestic and international policy makers when it comes to economic modernization. However, as all the documents used in this study were from before 2019, the effects of the Covid-19 pandemic on Russia's economic goals has yet to be fully realized. Future research may continue the use of theoretical analysis to focus on the effects of the pandemic on Russia's modernization agenda and its relationship with the EU.

Future research could also take a more quantitative approach, using statistical analysis of economic data to study the feasibility of the broader goals in Russia's modernization agenda, such as the goal of domestic economic growth rates exceeding global rates. This approach could be used alongside a theoretical analysis to further the understanding of not only what stands in the way of achieving these goals, but also what quantitative benchmarks would need to be reached in order to achieve them. Whether or not it is used in combination with another method, using a level-of-analysis approach allows researchers and policy makers to understand the interactions between domestic politics and international relationships, as well as how policy impacts both domestic and international stakeholders.

\section{Acknowledgments}

I thank Jill Berge (Lake Washington High School) for her guidance and support provided throughout the year-long research process; I thank Matthew Macomber (Lake Washington High School) for his tutelage during AP Seminar and the advice and edits I received in his class. 


\section{References}

Alexander, A. (2019). Russian economy in 2018 outlook and trends (Publication No. 40). Gaidar Institute for Economic Policy.

Bellamy, R., \& Weale, A. (2015). Political legitimacy and European monetary union: Contracts, constitutionalism and the normative logic of two-level games. Journal of European Public Policy, 22(2), 257-274. https://doi.org/10.1080/13501763.2014.995118

Bjola, C., \& Manor, I. (2018). Revisiting Putnam's two-level game theory in the digital age: domestic digital diplomacy and the Iran nuclear deal. Cambridge Review of International Affairs, 31(1), 3-32. https://doi.org/10.1080/09557571.2018.1476836

Commission staff working document on significant distortions in the economy of the Russian Federation for the purposes of trade defence investigations. (2020, October 22). European Commission.

Connolly, R. (2015). Economic modernization in Russia: the roles of the world trade organization. European Politics and Society, 16(1), 27-44. https://doi.org/10.1080/15705854.2014.965891

David, M., \& Romanova, T. (2015). Modernization in EU-Russian relations: Past, present, and future. European Politics and Society, 16(1), 1-10. https://.doi.org/10.1080/15705854.2014.965895

Flenley, P. (2015). The partnership for modernization: Contradictions of the Russian modernization agenda. European Politics and Society, 16(1), 11-26. http://doi.org/10.1080/15705854.2014.965583

Jabko, N. (2006). Playing the market: A political strategy for uniting Europe 1985-2005. Cornell University Press.

Korteweg, R. (2018, April 27). Energy as a tool of foreign policy of authoritarian states , in particular Russia. European Parliament. http://doi.org/10.2861/951739

Len'chuk, E. B., \& Filatov, V. I. (2018). Strategic planning-- the way toward sustainable development of the Russian economy. Economic and Social Changes: Facts, Trends, Forecast, 11(4), 35-47. https://doi.org/10.15838

Levitov, A. (2016). Normative legitimacy and the state. Oxford Handbook, 1-21. https://doi.org/10.1093/oxfordhb/9780199935307.013.131

PJSC "RusHydro" equity capital structure as of 31.12.2020 [Chart]. (2020, December 31). RusHydro. http://www.eng.rushydro.ru/investors/stock-market/capital/

Putin, V. (2018, March 1). Presidential address to the federal assembly [Speech transcript]. Kremlin. http://en.krem$\underline{\text { lin.ru/events/president/news/56957 }}$

Putin, V. (2018, May 7) Exec. Order No. 204, [Federal Document]

Putnam, R. D. (1988). Diplomacy and domestic politics: The logic of two-level games. The MIT Press, 42(3), $427-$ 460. 
Roadmap EU-Russia energy cooperation until 2050 [Press release]. (2013, March).

Road map for the common economic space- building blocks for sustained economic growth [Paper presentation]. (2003, May). St. Petersburg Summit, St. Petersburg, Russia. Europa.

Romanova, T. (2015). The partnership for modernization through the three level-of-analysis perspectives. European Politics and Society, 16(1), 45-61. https://doi.org/10.1080/15705854.2014.965900

Russell, M. (2018, July). Seven economic challenges for Russia. European Parliament. https://doi.org/10.2861/227260

Wiegand, G., \& Likhachev, A. (2012, December 21). Progress report agreed upon by the coordinators of the EURussia partnership for modernization for information to the EU-Russia summit of 21 December 2012. 